\title{
CATALASE ACTIVITY OF DIFFERENT CANDIDA SPECIES AFTER EXPOSITION TO SPECIFIC ANTISERUM
}

\author{
Natália R.S. Miyasaka ${ }^{1,2}$; Carmelinda S. Unterkircher ${ }^{3}$; Mario T. Shimizu ${ }^{3 *}$ \\ ${ }^{1}$ Instituto de Ciências Biomédicas, Universidade de São Paulo, Departamento de Microbiologia, São Paulo, SP, Brasil; \\ ${ }^{2}$ Universidade São Francisco, Departamento de Microbiologia e Imunologia, Bragança Paulista, SP, Brasil; ${ }^{3}$ Universidade \\ Estadual Paulista, Departamento de Microbiologia, São Paulo, SP, Brasil.
}

Submitted: July 23, 2007; Returned to authors for corrections: September 22, 2007; Approved: January 23, 2008.

\begin{abstract}
Antisera were developed in rabbits after challenge with intracellular antigens of Candida albicans, $C$. tropicalis and C. parapsilosis. Microorganism catalase has been correlated with virulence, resistance to drugs and immunogenicity. The intracellular catalase is consistently present in strains of Candida and in this paper, the enzyme activity was analysed by PAGE after exposition to antisera. The catalases of $C$. albicans, $C$. parapsilosis and C. tropicalis were immunogenic and differed in their binding to specific antibodies raised in rabbits. Tests of cross-reactivity between different Candida species showed that when antiserum from $C$. albicans immunized rabbit was incubated with intracellular extracts of these three Candida species, the catalases activities were abolished. However, the antisera from C. parapsilosis or C. tropicalis immunized rabbits did not affect the catalase activity of $C$. albicans; the enzyme of $C$. albicans was inactivated only by the antiserum to the catalase of own $C$. albicans. The antiserum to the catalase of $C$. tropicalis was species-specific and did not cross-react with catalases of C. albicans and C. parapsilosis. The activities of Aspergillus niger and bovine catalases were not affected by the antiserum from any Candida immunized rabbits. This report is a preliminary study of specific antisera that react against intracellular catalase of Candida sp. and neutralize the enzymatic activity. Further study is necessary to develop speciesspecific antibody once differences in the susceptibility of the Candida species to commonly used antifungal drugs make identification to the species level important.
\end{abstract}

Key words: candidiasis, catalase, Candida, antigen, diagnosis

\section{INTRODUCTION}

The incidence of infections caused by Candida species has been rising for decades. The Candida genus is the fourth most common group of microorganisms recovered from the bloodstream of patients in the United States (6). Similarly, the rates of Candida infections have increased substantially in Europe (17) and in Brazil (4). C. albicans is the most frequent species isolated, but many studies have documented an increase in the prevalence of different species of Candida such as $C$. tropicalis, C. parapsilosis $(3,4)$.
Invasive candidiasis is associated with high morbidity and mortality. Clinical diagnosis is complicated by a lack of specific clinical signs and symptoms of disease. Early recognition is important in order to reduce candidiasis related mortality (9). Microbiological confirmation is difficult because blood cultures lack sensitivity, widely reported to be less than $50 \%$ for deep-seated infections (11). Serological markers (antibodies and antigens) of Candida infection have been investigated which could be used to facilitate the diagnosis of candidiasis through immunological techniques $(5,17)$.

*Corresponding Author. Mailing address: Av. Jorn. Napoleão Monteiro, 179, Jardim Colinas. CEP 12242-180, São José dos Campos, SP, Brasil. E-mail: mtshimizu@terra.com.br 
In the process of invading host tissue there is an increase in fungal-specific products resulting from normal excretory or secretory mechanisms, natural autolysis and an attempt by the host to damage or destroy the invading pathogen. These excretory, secretory or breakdown products can potentially be utilized as specific markers of systemic disease (13).

Enzymes, including catalase have been shown to possess antigenic activity and have been used in diagnostic tests for aspergillosis (8) and histoplasmosis (7). The catalase of Candida has not been explored yet as antigen that could be used as a specific marker of candidiasis.

The catalases of different Candida species were characterized in a previous paper (10) and determined the electrophoretical profile in non-denaturating polyacrylamide gel and the physico-chemical properties. The aim of this study was to develop the specific antisera after challenge with intracellular antigens of $C$. albicans, $C$. tropicalis and $C$. parapsilosis that may react with the catalases of these yeasts.

\section{MATERIALS AND METHODS}

\section{Preparation of Candida antigens}

Candida albicans ICB7, C. parapsilosis ICB02 and $C$. tropicalis FCF427 were grown in Sabouraud dextrose broth (Difco, Detroit, USA), shaking for $48 \mathrm{~h}$ at $37^{\circ} \mathrm{C}$. These strains were isolated, identified and used in the studies reported previously (15). The cells were harvested by centrifugation and disrupted with glass beads (710-1180 mm, Sigma, St. Louis, USA) at $5^{\circ} \mathrm{C}$. Cell debris was removed by centrifugation and the supernatant was concentrated by lyophilization. This supernatant constituted the water soluble (WS) material that contained the intracellular catalase.

\section{Protein analysis}

The total protein content of the WS material was determined by the Coomassie Blue dye-binding (1), with bovine serum albumin as a standard.

\section{Production of rabbit antisera}

Antisera were obtained by hyperimmunization of New Zealand White rabbits with WS fractions of C. albicans ICB7, C. parapsilosis ICB02 and C. tropicalis FCF427. Each of these fractions (at a protein concentration of $10 \mathrm{mg} \mathrm{ml}^{-1}$ ) was mixed with an equal volume of Freund's complete adjuvant (Difco, Detroit, USA) and the suspension was injected intradermally in multiple sites in a rabbit; 20 days later the same amount of antigen was mixed with an equal volume of Freund's incomplete adjuvant (Difco, Detroit, USA) and the suspension was injected intramuscularly into a buttock; 20 days later the suspension was injected intramuscularly into the other buttock; 15 days later the WS fraction (double volume) without adjuvant was injected intramuscularly into a buttock; one week later the animal was test-bled. Sera were collected from rabbits before injection of antigen to use as negative control (normal sera).

\section{Specific immunoglobulin-binding experiments}

Three different antisera were obtained after hyperimmunization of rabbits: antiserum to the catalase of $C$. tropicalis, antiserum to the catalase of $C$. parapasilosis and antiserum to the catalase of $C$. albicans. The cross-reactivities between each antiserum $(0.7-11.2 \mu \mathrm{l})$ and different catalases (catalase of $C$. tropicalis FCF427, $C$. parapsilosis ICB02, $C$. albicans ICB7, bovine catalase obtained from Amersham Pharmacia Biotech, Buckinghamshire, England and catalase of Aspergillus niger obtained from Sigma, St. Louis, USA) were tested. Each antiserum was incubated with the catalases for 1.5 $\mathrm{h}$ at $8^{\circ} \mathrm{C}$. After the incubation, each mixture was submitted to electrophoresis on non-denaturating polyacrylamide gel to detect the catalase activity.

The neutralization of catalase activity by specific immunoglobulin-binding could be observed by the absence of enzyme activity on non-denaturating polyacrylamide gels.

\section{Electrophoresis}

Electrophoresis was performed in non-denaturating gradient (4-30\%) polyacrylamide gels. The electrode buffer was $0.09 \mathrm{moll}^{-1}$ Tris, $0.08 \mathrm{moll}^{-1}$ boric acid and $0.0025 \mathrm{~mol} \mathrm{l}^{-1}$ disodium ethylenediaminetetraacetate, $\mathrm{pH} 8.4$ (2). Samples for analysis were loaded on the basis of the amount necessary to optimize the size and separation of the catalase bands (0.7-1.5 $\mu \mathrm{l})$ as padronized in previous study (10). High molecular weight protein standards utilized were thyroglobulin $(669 \mathrm{kDa})$, ferritin (440 kDa), bovine catalase $(232 \mathrm{kDa})$ and aldolase $(158 \mathrm{kDa})$ obtained from Amersham Pharmacia Biotech (Buckinghamshire, England).

\section{Detection of catalase activity}

The ferricyanide negative stain was used to locate bands with catalase activity, as described by Wayne and Diaz (18).

\section{RESULTS}

Differences in anti-catalase antibodies specificity raised in rabbits immunizated with intracellular extracts of C. albicans, C. parapsilosis and C. tropicalis were observed.

The samples contained catalase bands were separated on PAGE and the enzyme activity was detectable with the ferricyanide reagent as clear zones in the dark background. The absence of catalase activity on non-denaturating polyacrylamide gel showed that the enzyme was neutralized by specific immunoglobulin-binding present in the rabbit antiserum.

Antiserum to the catalase of $C$. tropicalis was specific to recognize only the catalase of own $C$. tropicalis. This antiserum had not effect when incubated with catalases of 
other Candida species ( $C$. parapsilosis and $C$. albicans). The normal sera (pre-immunization controls) had no natural antibodies or any other substances that inhibited the catalase activity (Fig. 1).

On the other hand, antiserum to the catalase of $C$. parapsilosis had specific binding to own catalase but also cross-reacted with catalase of $C$. tropicalis. The antibodies present in the antiserum to the catalase of $C$. parapsilosis abolished the catalase activity of $C$. parapsilosis and $C$. tropicalis and had no effect on the enzyme activity of $C$. albicans. The bovine catalase was also not affected (Fig. 2). The same results were observed after incubation of the bovine catalase with antisera to the catalase of $C$. albicans and $C$. tropicalis (data not shown).

Differently, antiserum to the catalase of $C$. albicans caused a loss of catalases activities of three Candida species $(C$. tropicalis, $C$. parapsilosis and $C$. albicans). It had no effect on Aspergillus niger catalases (Fig. 3). Electrophoretic variants of A. niger catalase were detected on PAGE and no one was affected by the antisera to the Candida species.

\section{DISCUSSION}

Many immunologically reactive molecules of Aspergillus species are glycoproteins like catalase (8) and evidences that the $\mathrm{M}$ antigen of Histoplasma capsulatum var. capsulatum is a catalase was reported by Hamilton et al. (7). $\mathrm{M}$ antigen is

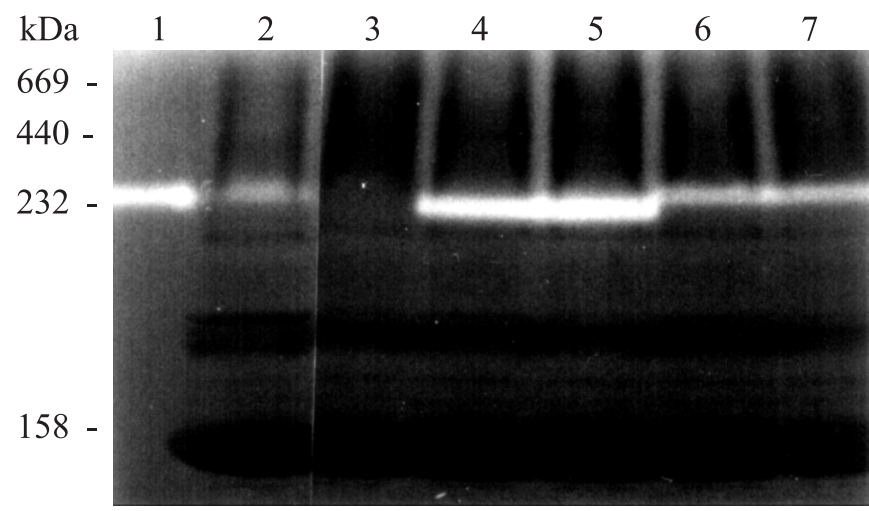

Figure 1. Electrophoresis on non-denaturating polyacrylamide gradient gel of catalases of different Candida species after incubation with normal rabbit serum (NS, control) and antiserum to the catalase of $C$. tropicalis (AS-C.t.). Lanes: (1) Bovine catalase (comercial); (2) Catalase of $C$. tropicalis $+\mathrm{NS}$; (3) Catalase of C. tropicalis + AS-C.t.; (4) Catalase of C. albicans $+\mathrm{NS}$; (5) Catalase of C. albicans + AS-C.t.; (6) Catalase of $C$. parapsilosis + NS; (7) Catalase of C. parapsilosis + AS-C.t. Molecular weight markers: Thyroglobulin (669 kDa), ferritin (440 $\mathrm{kDa})$, bovine catalase $(232 \mathrm{kDa})$ and aldolase $(158 \mathrm{kDa})$.

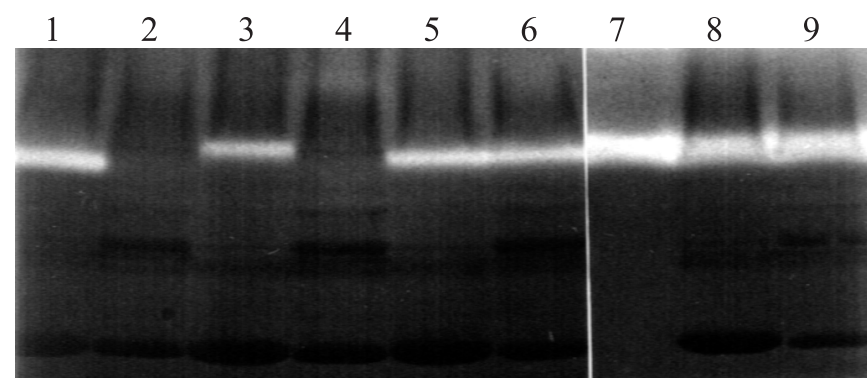

Figure 2. Electrophoresis on non-denaturating polyacrylamide gradient gel of different Candida species and bovine catalases after incubation with normal rabbit serum (NS, control) and antiserum to the catalase of $C$. parapsilosis (AS-C.p.). Lanes: (1) Catalase of $C$. parapsilosis + NS; (2) Catalase of $C$. parapsilosis + AS-C.p.; (3) Catalase of C. tropicalis + NS; (4) Catalase of C. tropicalis $+\mathrm{AS}-C . p$. ; (5) Catalase of C. albicans + NS; (6) Catalase of C. albicans + AS-C.p.; (7) Bovine catalase (comercial) and (8) with NS; (9) Bovine catalase + AS-C.p.

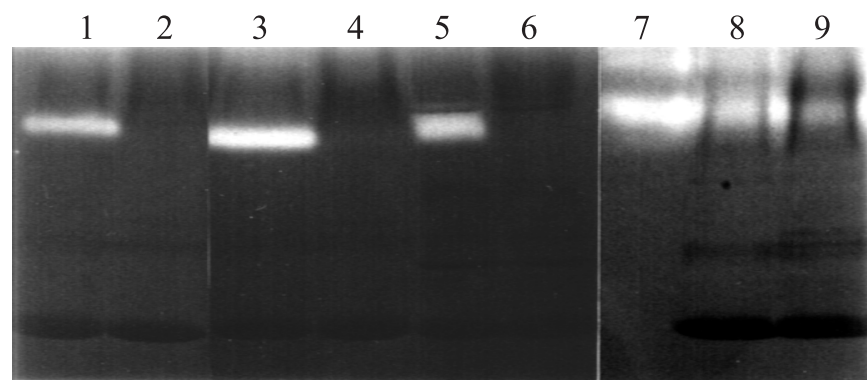

Figure 3. Electrophoresis on non-denaturating polyacrylamide gradient gel of catalases of different Candida species after incubation with normal rabbit serum (NS, control) and antiserum to the catalase of $C$. albicans (AS-C.a.). Lanes: (1) Catalase of C. albicans + NS; (2) Catalase of C. albicans + AS-C.a.; (3) Catalase of $C$. parapsilosis $+\mathrm{NS}$; (4) Catalase of $C$. parapsilosis +AS-C.a.; (5) Catalase of C. tropicalis + NS; (6) Catalase of $C$. tropicalis + AS-C.a.; (7) Catalases of A. niger (comercial) and (8) with NS; (9) Catalases of A. niger + AS-C.a.

considered immunodominant antigens of $H$. capsulatum because it is expressed during infection. This antigen is a marker of disease activity in histoplasmosis patients (12).

The present study showed that the catalase of Candida was immunogenic in rabbits and the immunization with intracellular fractions (WS) of different species of Candida raised specific antibodies that were able to neutralize the enzyme activity. None of the antisera reacted with catalases obtained from other organism such the filamentous fungi Aspergillus niger and bovine catalase, suggesting the existence of specific 
epitopes for Candida genus antibodies. Two catalase bands of A. niger were detected on electrophoresis and no one reacted with any antiserum to the catalase of Candida species.

Schonheyder et al. (14) reported that the antiserum to the catalases of Aspergillus fumigatus cross-reacted with catalase antigens of A. flavus, A. terreus and A. nidulans, but not of $A$. niger. In the present study, the antiserum to the catalase of $C$. parapsilosis cross-reacted with catalase of $C$. tropicalis but had no effect on catalase of $C$. albicans. Species-specificity was observed on antiserum to the catalase of $C$. tropicalis that did not cross-react with catalase of $C$. parapsilosis or $C$. albicans. On the other hand, the antiserum to the catalase of $C$. albicans cross-reacted with all Candida species tested. Thus, the antibody to $C$. albicans is not able to identify the species, but might be used as marker for the laboratory diagnosis for Candida sp. infections.

Immunochemical studies of catalase of $C$. tropicalis showed the immunogenicity of this enzyme (16); the formation of the immunocomplex was observed by Ouchterlony doublediffusion; the control serum from a nonimmunized rabbit did not affect the enzyme activity, but the antiserum prepared against catalase of $C$. tropicalis completely immuno-reacted with the enzyme in the crude extract and the purified enzyme from the crude extract. According to the authors, the antigenantibody complex itself possessed some activity. In the present study, the activity of Candida catalase was not observed after incubation with antiserum.

Electrophoresis in non-denaturating polyacrylamide gel (PAGE) showed an intracellular catalase of $C$. tropicalis FCF427, C. parapsilosis ICB02 and C. albicans ICB7 with an apparent molecular weight of $230 \mathrm{kDa}$ and it was consistently present in all WS preparations (10). Because it is consistently present in strains of Candida, it may be readily identified as an antigenenzyme.

Molecular weight determination by the ultracentrifugal analysis gave an approximate value of $210 \mathrm{kDa}$ to catalase of $C$. tropicalis (16). Electrophoresis on polyacrylamide gel in the presence of sodium dodecylsulfate (SDS-PAGE), the protein showed a single band of approximate molecular weight of 54 $\mathrm{kDa}$ and according to the authors, these results suggest that the enzyme consists of four identical subunits.

Similar electrophoresis results were obtained by Greenfield and Jones (5) with a purified cytoplasmic antigen of $C$. albicans. According to the authors, the antigen is a glycoprotein and gave a single protein band during SDS-PAGE and had the mobility expected for a molecule having a molecular weight of $54.3 \mathrm{kDa}$ (range, 48.9 to $59.7 \mathrm{kDa}$ ). The authors concluded that this antigen is present at high concentration in cytoplasmic extracts and it may be a structural component of the microorganism. Although more extensive studies are necessary, our data do suggest that the catalase of Candida may be a potential antigen.
Despite the advance on non-culture based diagnostic tests for candidiasis, the diagnosis of deep-seated Candida infections remains a great challenge. In the present study, species-specificity was observed on antiserum to the catalase of $C$. tropicalis but it was not observed on antiserum to the catalase of $C$. parapsilosis or C. albicans. Further study is necessary to develop species-specific antibody once differences in the susceptibility of the Candida species to commonly used antifungal drugs make identification to the species level important.

\section{ACKNOWLEDGEMENTS}

This research was supported by FAPESP (Fundação de Amparo à Pesquisa do Estado de São Paulo).

\section{RESUMO}

\section{Atividade de catalase em Candida sp. após exposição a antisoro específico}

Antisoros foram desenvolvidos em animais em resposta à injeção de antígenos intracelulares de Candida albicans, $C$. tropicalis e C. parapsilosis. A presença de catalase nos microrganismos tem sido relacionada à virulência, resistência a drogas e imunogenicidade. A catalase intracelular está sempre presente nas cepas de leveduras do gênero Candida e neste trabalho, sua atividade enzimática foi analisada por PAGE, após exposição aos antisoros obtidos. Verificou-se que as catalases de C. albicans, C. tropicalis e C. parapsilosis foram imunogênicas e apresentaram diferenças quanto à sua ligação aos anticorpos específicos produzidos nos coelhos. Testes de reação cruzada mostraram que quando o antisoro obtido do animal imunizado com C. albicans foi incubado com os extratos intracelulares de cada uma das três espécies, a atividade da catalase intracelular foi neutralizada em todos os casos. Entretanto, os antisoros obtidos da imunização com $C$. parapsilosis e $C$. tropicalis não afetaram a atividade da catalase de C. albicans; a catalase de $C$. albicans foi neutralizada somente pelo antisoro específico. $\mathrm{O}$ antisoro anti-C. tropicalis foi espécie-específico e não reagiu com as catalases de $C$. albicans e $C$. parapsilosis. As atividades das catalases bovina e de Aspergillus niger não foram afetadas por nenhum dos antisoros produzidos contra Candida sp. Este trabalho é uma análise preliminar de antisoros específicos reagentes com a catalase intracelular de Candida sp., capazes de neutralizar a atividade enzimática. Novos estudos são importantes para o desenvolvimento de anticorpo espécie-específico, uma vez que diferentes espécies de Candida apresentam diferente susceptibilidade aos antifúngicos de uso corrente.

Palavras-chaves: candidíase, catalase, Candida, antígeno, diagnóstico 


\section{REFERENCES}

1. Bradford, M.M. (1976). A rapid and sensitive method for the quantification of microgram quantities of protein utilizing the principle of protein-dye binding. Anal. Biochem., 72, 148-274.

2. Campbell, W.P.; Wrigley, C.W.; Margolis, J. (1983). Electrophoresis of small proteins in highly concentrated and crosslinked polyacrylamide gradient gels. Anal. Biochem., 129, 31-36.

3. Ellepola, A.N.B; Morrison, C.J. (2005). Laboratory diagnosis of invasive candidiasis. J. Microbiol., 43, 65-84.

4. Fernandes, A.C.S.; Souza Junior, F.C.; Oliveira, S.M.; Calich, L.; Milan, E.P. (2007). Prevalence of Candida species in umbilical catheters implanted in newborns in Natal, Brazil. Braz. J. Microbiol. 38, 104-107.

5. Greenfield, R.A.; Jones, J.M. (1981). Purification and characterization of a major cytoplasmic antigen of Candida albicans. Infec. Immun., 34, 469-477.

6. Gudlaugsson, O.; Gillespie, S.; Lee, K.; Vande Berg, J.; Hu, J.; Messer, S.; Herwaldt, L.; Pfaller, M.A.; Diekema, D. (2003). Attributable mortality of nosocomial candidemia, revisited. Clin. Infect. Dis., 37, 1172-1177.

7. Hamilton, A.J.; Bartholomew, M.A.; Figueroa, J., Fenelon, L.E.; Hay, R.J. (1990). Evidence that the M antigem of Histoplasma capsulatum var. capsulatum is a catalase which exhibits crossreactivity with other dimorphic fungi. J. Med. Vet. Mycol., 28 , 479-485.

8. Hearn, V.M.; Shimizu, M. (1996). Effects of tunicamycin on glycoprotein antigens of Aspergillus fumigatus. Microbios, 85, 239-250.
9. Mitsutake, K.; Kohno, S.; Miyazaki, T.; Miyazaki H.; Maesaki, S.; Koga, H. (1994). Detection of Candida enolase antibody in patients with candidiasis. J. Clin. Lab. Anal., 8, 207-210.

10. Miyasaka, N.R.S.; Unterkircher, C.S.; Carvalho, P.O.; Shimizu, M.T. (2004). Electrophoretic variants of intracellular catalase of different Candida species. Mycopathologia, 158, 187-193.

11. Reiss, E.; Morrison, C.J. (1993). Nonculture methods for diagnosis of disseminated candidiasis. Clin. Microbiol. Rev., 6, 311-323.

12. Reiss, E.; Obayashi, T.; Orle, K.; Yoshida, M.; Zancopé-Oliveira, R.M. (2000). Non-culture based diagnostic tests for mycotic infections. Med. Mycol., 38, 147-159.

13. Richardson M.D.; Kokki, M.H. (1999). New perspective in the diagnosis of systemic fungal infections. Ann. Med., 31, 327-335.

14. Schonheyder, H.; Anderson, P.; Petersen, J.C. (1985). Rapid immunoelectrophoretic assay for detection of serum antibodies to Aspergillus fumigatus catalase in patients with pulmonary aspergillosis. Eur. J. Clin. Microbiol., 4, 299-303.

15. Shimizu, M.T.; Jorge, A.O.C.; Unterkircher, C.S.; Fantinato, V.; Paula, C.R. (1995). Hyaluronidase and chondroitin sulphatase production by different species of Candida. J. Med. Vet. Mycol., 33, 27-31.

16. Yamada, T.; Tanaka, A.; Fukui, S. (1982). Properties of catalase purified from whole cells and peroxisomes of n-alkane grown Candida tropicalis. Eur. J. Biochem., 125, 517-521.

17. Yera, H.; Sendid, B.; Francois, N.; Camus, D.; Poulain, D. (2001) Contribution of serological tests and blood culture to the early diagnosis of systemic candidiasis. Eur. J. Clin. Microbiol. Infect. Dis., 20, 864-870.

18. Wayne, L.G.; Diaz, G.A. (1986). A double staining method for differentiating between two classes of mycobacterial catalase in polyacrylamide electrophoresis gels. Anal. Biochem., 157, 89-92. 